\title{
Sustainable Environmental Management and Valorization Options for Olive Mill Byproducts in the Middle East and North Africa (MENA) Region
}

\author{
Adnan Khdair ${ }^{1,2, *(\mathbb{D})}$ and Ghaida Abu-Rumman ${ }^{3}$ \\ 1 Department of Mechanical Engineering, King Abdulaziz University, P.O. Box 80204, 21589 Jeddah, Saudi \\ 2 Department of Mechanical Engineering, Jordan University of Science and Technology, P.O. Box 3030, \\ 2011 Irbid, Jordan \\ 3 Department of Civil Engineering, Isra University, 11622 Amman, Jordan; ghaida.rumman@iu.edu.jo \\ * Correspondence: akhdair@kau.edu.sa or akhdair@just.edu.jo
}

Received: 8 May 2020; Accepted: 26 May 2020; Published: 5 June 2020

\begin{abstract}
Cultivation of olive trees and olive oil production have been considered as a legacy for the Mediterranean region. This custom represents a very important benefit for many nations in terms of wealth and health. However, huge amounts of by-products and waste are generated during olive oil production. This represents a serious environmental impact on land and water bodies if not properly handled. Olive oil extraction generates two waste streams, a solid waste called pomace and olive mill wastewater (OMWW), which has been considered as highly pollutant and phytotoxic waste. These wastes have high disposal costs and predominantly generated from small-scale enterprises that have limited financial resources to treat them properly before discharge to the environment. Besides being a serious environmental problem, OMWW has potential economic value that remains to be utilized such as: fertilizers, valuable antioxidants agents and fatty acids needed in human diet. Also, Olive pomace is a valuable renewable energy source with an energy density of $23 \mathrm{MJ} / \mathrm{kg}$ and has become an inexpensive alternative for fossil fuels. Aiming at adding value to the olive production sectors and potential valorization options for byproducts in the MENA region, international practices applied in olive mills wastes management's and treatment methods used in major oil producing countries are presented.
\end{abstract}

Keywords: olive mill wastewater; Zibar; olive Pomace; Jift; treatment; valorization; cleaner production; disposal

\section{Introduction}

Olives trees (Olea europaea L.) cultivation and olive oil production have deep roots in the history of Mediterranean region. The centuries old tradition represents a very important asset for many countries in the region, not only in terms of culture and health but also in terms of wealth. The olive oil production is increasing over time due to the increase in olive trees cultivation and customers high demand. Over the past few decades, olive oil represents an important healthy dietary trend worldwide, because it is considered as important resource of essential fatty acids and antioxidants agents in human diet [1].

According to latest estimations by Reference [2], approximately 11 Mha of olive groves were cultivated in 2015 worldwide. Roughly $50 \%$ of these groves' cultivations are in EU countries, especially Spain $(24.2 \%)$, Italy $(11.1 \%)$ and Greece $(9.0 \%)$. Total olive fruit production in the EU accounted for $13.24 \mathrm{Mt}$, again Spain is the major producer with $7.87 \mathrm{Mt}(60 \%)$ of total EU yield. The annual global olive oil production is around 3.32 million, with $72 \%$ produced in Europe [2]. 
Olive oil main producers are Spain (42\%), Italy (17\%) and Greece (11\%), other Mediterranean countries producers are Turkey, Syria and Tunisia with (6\%) each and Morocco (4\%), Jordan (3\%) and Lebanon (1.5\%). Other smaller producers outside Mediterranean basin in Asia, Africa and America are growing with $15 \%, 12 \%$ and $2 \%$ of worldwide olive production, respectively [2].

Olive groves are the main agricultural plantation over the eastern Mediterranean. Olive orchards are typically small and located in hilly areas and therefore difficult to access and expensive to harvest by hand [3]. In addition to the nutritional value in its products, olive trees have significant social and economic importance in the life of the people living in Mediterranean countries. The biomass residues from olive trimming and olive mill byproducts after drying and pelleting have become an important source of renewable energy and an inexpensive alternative to traditional fossil fuels used in home heating in rural areas. In Mediterranean countries where soils are poor in organic matter and vigorous desertification processes are in play, the recycling of olive mill wastewater (OMWW) as a soil amendment should be encouraged.

The environmental impact of olive oil production is critical in all olive oil producing countries in the Mediterranean. The oil extraction processes need a significant amount of water and produces huge amounts of olive mill wastes (OMWs) in short period of time (October-January) of olive harvesting season [3-11].

Management of (OMWs) is considered a major environmental challenge in Mediterranean region. Olive oil extraction generate two types of waste streams: a liquid stream called (OMWW) or locally named "Zibar" and a solid residue known as pomace, locally referred to as "Jift." Olive mills dispose their OMWW in settling ponds that are normally under-sized and sometimes get overloaded causing spillage to nearby valleys [3,4]. There are no proper facilities for treatment of OMWW in individual mills, so their minimization, prevention and treatment, have long been investigated to reduce their environmental impacts caused by their uncontrolled disposal [12]. The wastewater is also a major source of odor and can be harmful to plants if irrigated at high OMWW concentration.

Therefore, guidelines should be set to handle these wastes streams properly by adopting technologies that minimize their generation and increase awareness, motivation within the industry and by introducing cleaner production options for farmers to minimize their environmental impact and increase resource sustainability. Management of this wastewater has been considered in the past three decades with special attention to its safe treatment and possible valorization [13].

The effects of application of OMWW on the environment, on soil properties and on olive tree performance were studied by many local researchers [14-17]. Their results showed that application of OMWW did not have any negative effect on soil properties. It served as a beneficial soil amendment particularly in providing plant macronutrients (nitrogen, phosphorus and potassium) along with organic matter that is beneficial to soils [15-23].

To improve land fertility and olive trees performance, the recommended application of OMWW to olive orchards is $100 \mathrm{~m}^{3} / \mathrm{ha}\left(10 \mathrm{~L} / \mathrm{m}^{2}\right)$ [14-18]. It was reported that the concentrations of organic matter, phenolic compounds, potassium and microbial activities were considerably enhanced in soil amended with OMWW [14]. Furthermore, a substantial increase in plant growth, photosynthesis and fruit production were also observed without affecting oil quality parameters. On the other hand, short-term deleterious effects on soil biological activities and chemical properties were noticed after OMWW application but it can be considered insignificant after appropriate waiting time [24]. For toxicity mitigation, it was recommended applications of OMWW six months before sowing of maize [25]. Beside the right selection of suitable soils (particularly calcareous soils) and tolerant crops, like maize, this approach might be considered as an effective method to avoid problems associated with OMWW uncontrolled disposal and represents an economical opportunity by providing cheap available local fertilizer.

The uncontrolled disposal of OMWs on soil results in decreases in water retention and infiltration rate, increases soil hydrophobicity and causes strong phytotoxic and antimicrobial effects, in addition to 
affects soil acidity, salinity, nitrogen immobilization, nutrient leakage, organic acids, lipids concentration, naturally occurred phenols and microbial activity [26].

In this study, the status of olive by-products management is presented, along with their present utilization and techniques applied in major oil producing countries. Alternative options that can be adopted for eliminating possible environmental problems associated with uncontrolled disposal of olive mill byproducts are investigated. Aiming at adding value to the olive oil industry in Middle East and North Africa (MENA) region, international best practices applied to solid waste and wastewaters treatment as well as potential valorization options are also highlighted.

\section{Olive Harvesting and Processing Methods}

In the (MENA) region countries, olives are typically harvested by hand because of the small sizes of orchards in addition to small farm holding. Harvested fruits are gathered in sacks and transported to olive mills for further processing. The traditional press process is the oldest method for obtaining olive oil from fruits. Significant industrial development has been made in olive oil manufacturing in the past three decades aiming at reducing water consumption and related potential environmental impacts. To improve extraction efficiency, the industry developed continuous centrifugation systems to obtain better quality of olive oil produced while reducing waste generation by $75 \%$ [27]. Nowadays, most conventional olive oil mills have been replaced by continuous centrifugal systems that is, ecological decanters [27].

\section{Olive Oil Processing Systems and By-Products Characteristics}

Olive oil is extracted from olives by mechanical means. Three methods are used namely: the traditional press, the three-phase centrifugation and currently the two-phase ecological decanter systems used since 1990 [7,8]. The three-phase centrifugation system produces two by-products: solid by-product that consists mainly of olive pulps and stones called olive pomace with a humidity of about $55 \%$ and the OMWW consists of olive fruit water and water used washing and processing olives $[7,28]$. The three-phase method normally produces around $20 \%$ olive oil, $30 \%$ olive pomace and $50 \%$ OMWW, which indicates that wastes produced are four times more than olive oil. The two-phase systems require small quantities of water for oil extraction, thus smaller amounts of wastes are generated.

Olive oil extraction process steps include washing of olive fruit, crushing of fruit, malaxation and separation and finally the extraction of oil. Malaxation is the process of mixing milled olives for 20 to $40 \mathrm{~min}$ at $27^{\circ} \mathrm{C}$ allowing smaller oil droplets to aggregate and be separated more easily. The effectiveness of oil extraction yield is a function of mixing time and maintaining the desired temperature. The extraction at higher temperatures implies that the oil cannot be labeled "cold pressed," a process that is preferred by consumers. [29].

Input-output analysis of each extraction process is illustrated in Figure 1. Olive oil production starts with the washing of olives to remove any dirt and other contaminants (e.g., leaves and twigs). Water usage at the mills depends on pressing methods and operational practices. Average volume of OMWW generated ranges from 0.3 to $1.2 \mathrm{~m}^{3} /$ ton of processed olives (Table 1). In 3-phase mills, average freshwater consumptions range from 700-1000 L/ton of olives processed and the generated OMWW is $1200 \mathrm{~L} /$ ton, the highest of all processes. Corresponding figures for 2-phase mills are 100-120 L/ton of freshwater consumed and $200 \mathrm{~L} /$ ton of OMWW generated. 


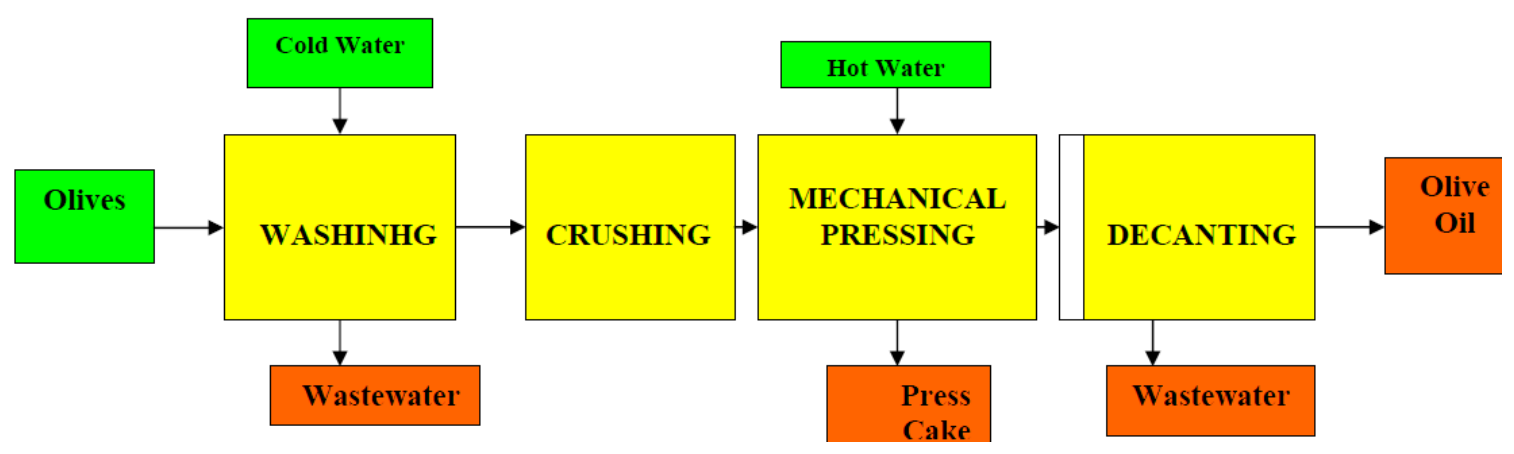

(a) Traditional oil extraction process

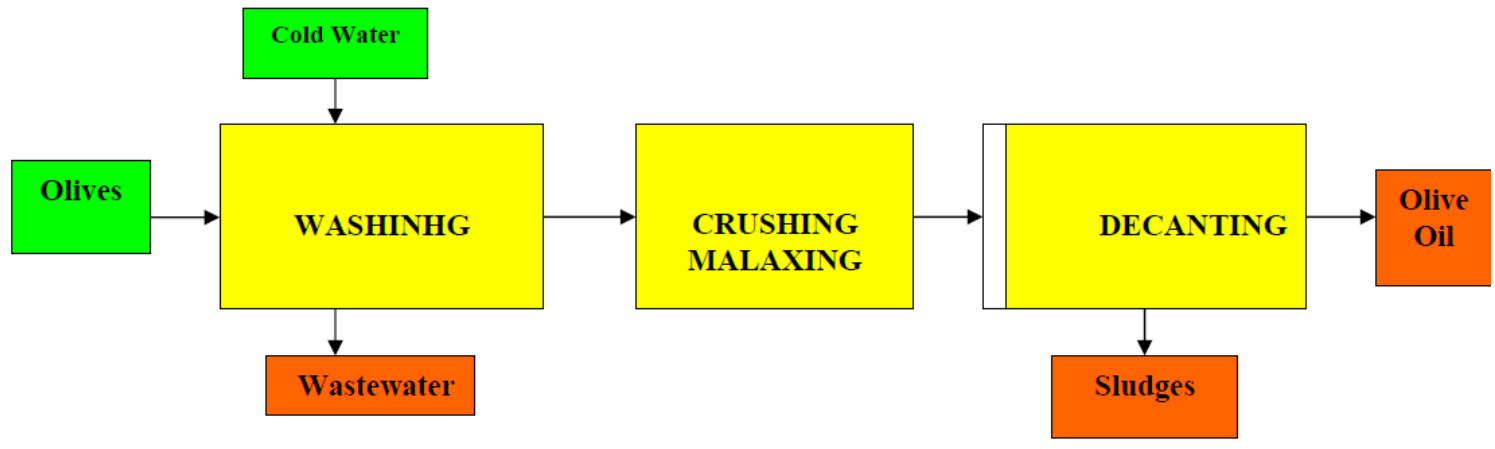

(b) 2-phase extraction process

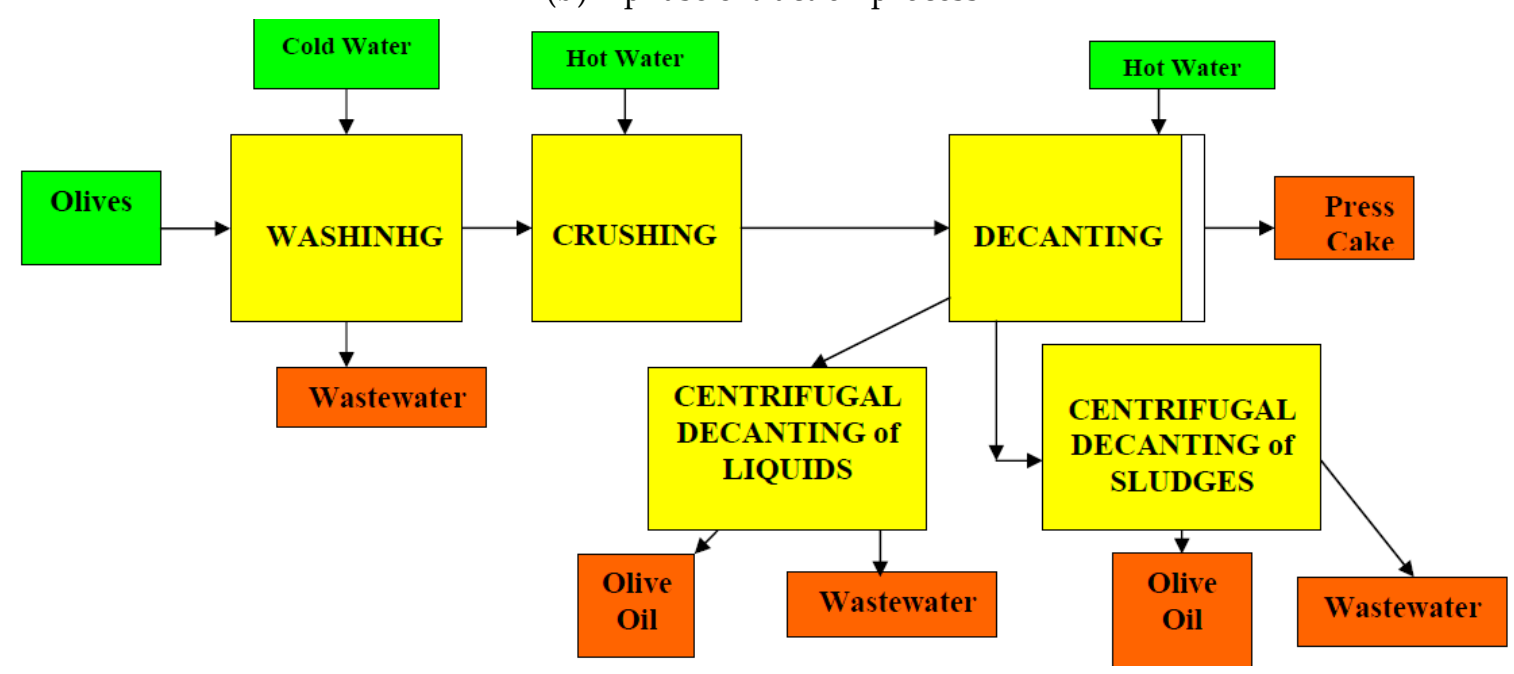

(c) 3-phase extraction process

Figure 1. Process flow chart of olive oil extraction methods. 
Table 1. Approximate input output analysis of water consumption and byproducts generated at olive oil mills $[3,30,31]$.

\begin{tabular}{ccccc}
\hline Mill Type & Input & Quantity & Output & Quantity \\
\hline \multirow{3}{*}{ Traditional } & Olive & $1000 \mathrm{~kg}$ & Oil & $230.4 \mathrm{~kg}$ \\
& Washing water & $100-200 \mathrm{~L}$ & Pomace & $500 \mathrm{~kg}$ \\
& & & Wastewater & $650 \mathrm{Liter}$ \\
\hline \multirow{3}{*}{ 3-Phase } & Olive & $1000 \mathrm{~kg}$ & Oil & $256.4 \mathrm{~kg}$ \\
& Washing water & $100-120 \mathrm{~L}$ & Pomace & 581.16 \\
& Hot water Added & $700-1000 \mathrm{~L}$ & Wastewater & $1200 \mathrm{~L}$ \\
\hline \multirow{3}{*}{ 2-Phase } & Olive & $1000 \mathrm{~kg}$ & Oil & $247.4 \mathrm{~kg}$ \\
& Washing water & $100-120 \mathrm{Liter}$ & Pomace & $735 \mathrm{~kg}$ \\
& & & Wastewater & $200-300$ \\
\hline
\end{tabular}

OMWW constitutes a suspension consists mainly of: $80-92 \%$ water, $3-15 \%$ organic matters such as oils and fats, carbohydrates, lipids, pectin, organic acids, sugars, mucilage, polysaccharides, phenols, tannins and lignin and $0.50-2 \%$ mineral content on a weight basis [10,32-39].

The effluent highest concentrations of biological oxygen demand (BOD) and chemical oxygen demand (COD) might reach 100 and $220 \mathrm{~g} / \mathrm{L}$, respectively [40], with high COD/BOD 5 ratio between $2-5[4,30,41]$. The chemical-physical properties of OMWW depend on olive cultivar, cultural practices, maturity (ripening stage of the olives), climate conditions, olive storage and oil production system $[4,20,35,36,42-46]$

The aromatic, long-chain fatty acids and polyphenolic compounds with concentration up to $80 \mathrm{~g} / \mathrm{L}$ are considered the major factors related to OMWW pollution characteristics because they are toxic to soil microorganisms and plants [47-49] and considered the most polluting waste generated by the agri-food industries [50-52]. Phenolic compounds are initially produced by the olive trees and developed later during the oil extraction processes [7]. Most of these compounds are soluble in water, so they go away with olive mill by-products and just a small amount is remained in the oil [53].

The two-phase extraction system was introduced to the olive oil mill industry in $1992[30,52]$ and considered as the most ecologically friendly techniques. These decanters generate smaller quantities of byproducts that are typically $75 \%$ less than what is generated while using the other two extraction methods [30], thus providing cost savings in wastewater treatment and disposal. However, the pomace produced in the two-phase system is excessively wet characterized by high humidity (62\%) [54], which is considered as a major drawback of this technique [32,54].

The increase in quantity of waste generated and their disposal without proper treatment causes environmental challenges because of its phytotoxicity and high organic matter content $[54,55]$. To alleviate these negative impacts, environmentally friendly waste management technique is required by law. The most common management practices are the use of lagoons or storage ponds located on mill sites that both allow wastewater to evaporate naturally and for solids (along with any heavy metals) to settle to the bottom of ponds [3,4].

\section{Current Management Practices of Olive Mills by Byproducts in the MENA Region}

The replacement of the three-phase mills with two-phase mills has reduced consumption of water throughout oil extraction processes. This change has a significant positive impact in most Mediterranean countries as these countries are also undergoing severe water shortages [3,4]. Additionally, the use of less water translates to generation of lower quantities of process byproducts. However, environmental concerns are not eliminated totally in this process. A semi-solid waste stream with a unique physical and chemical properties is produced leading to the need for a new management practice that is different from that of handling olive husks. This requires development of a new process that is technically feasible and economically affordable for managing this waste stream. 


\subsection{Management Practices of OMWW}

The increase in number of olive groves plantations over years has led to an increase in number of olive mills in the region. Wastewater generated at the mill is initially stored in concrete or otherwise sealed ponds and lagoons (Figure $2 \mathrm{a}-\mathrm{c}$ ). It is then transferred by tanks to officially designated sites. At the present time there are no OMWW treatment plants facilities operating in the MENA region. The discharge of OMWW to the municipal sewer system is totally prohibited because of its corrosive nature and the high concentration of suspended solids which may result in clogging of the wastewater network close to the olive mills.

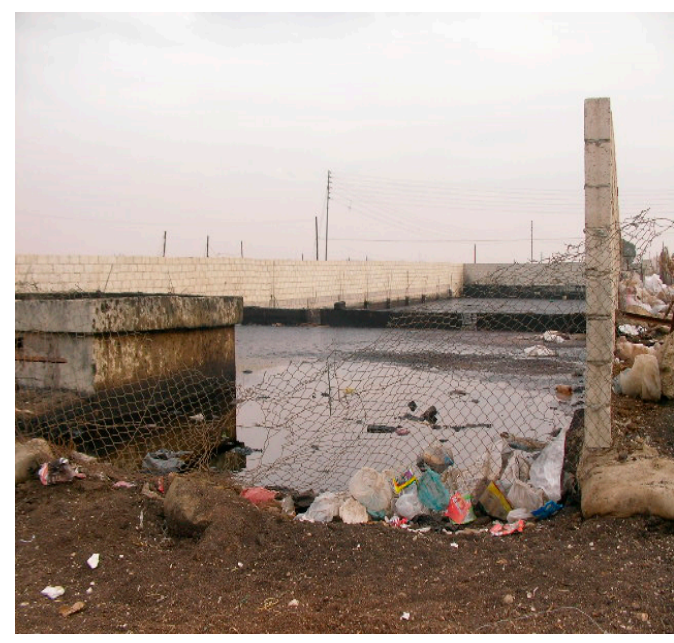

(a) Concrete pool

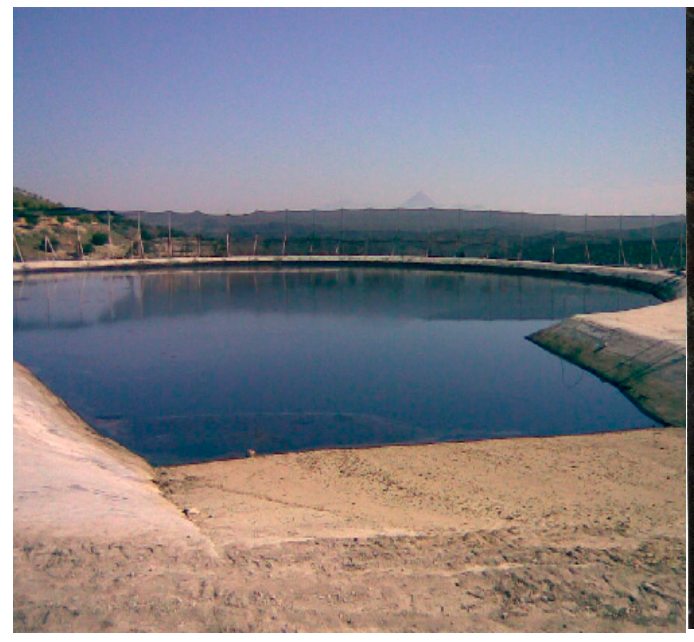

(c) Sealed Drying pond for OMMW

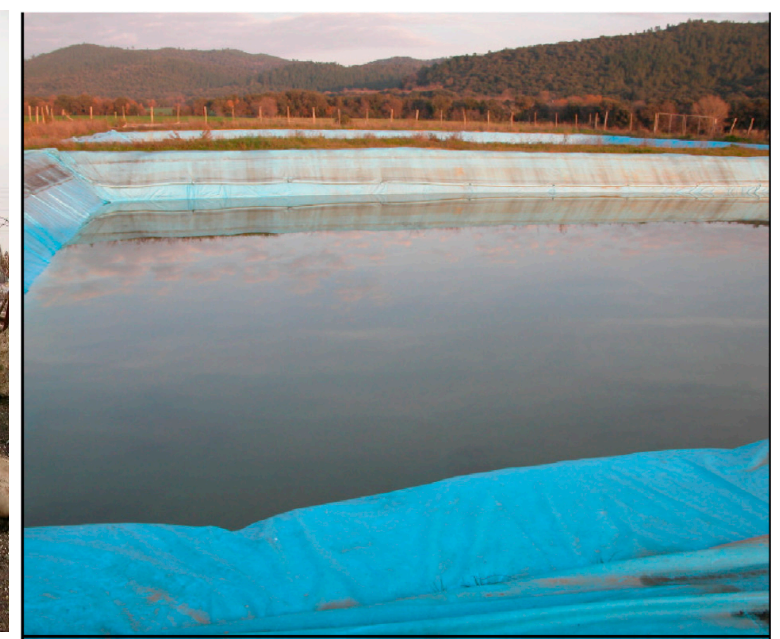

(b) Evaporation Lagoon

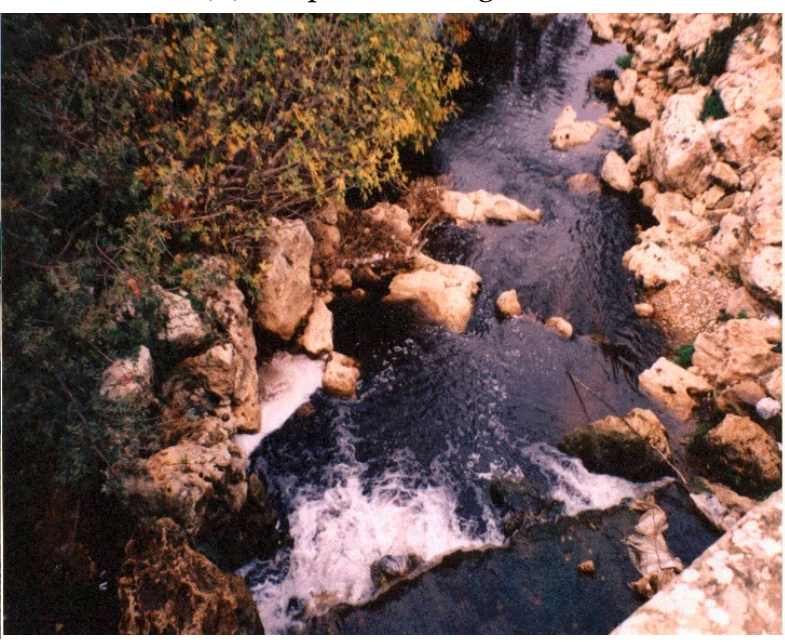

(d) Spring polluted with OMWW

Figure 2. Wastewater storage and handling at different locations of olive mills in Irbid area.

There are small gaps related to policy, legal and institutional framework for OMWW management in the region, which has sometimes resulted in environmental mismanagement, pollution and potential threat to scarce surface and groundwater resources as shown in Figure $2 \mathrm{~d}$. Due to its characteristics, OMWW is considered as an industrial wastewater and is regulated as such. It was reported that one cubic meter of OMWW has the equivalent environmental impact of 100-200 $\mathrm{m}^{3}$ of domestic sewage [10], while their discharge to lakes, rivers or sea have a severe effect on aquatic ecosystems because of eutrophication potential [55]. 
Olive mills in the MENA region are typically small to medium size enterprises, geographically scattered around countries sides, lacking financial resources and technical capabilities needed to develop an appropriate on sites OMWW treatment plant. Treatment methods have to be simple and inexpensive in order to help the olive mill owners to adopt it and raise their awareness to best management practices, especially in upgrading olive mills in order to enhance their global competitiveness and increase exports of processed oil. Many olive mills have implemented good manufacturing practices and have been able to get the Hazard Analysis and Critical Control Point (HACCP) certificate, representing expertise in a system of food safety protocols that are internationally recognized.

\subsection{Management Practices of Olive Pomace (Jift)}

The three-phase olive mill produce huge amounts of OMWW, in addition to huge amounts of solid wastes. Olive pomace (Jift) is the solid by-product, obtained by olives processing composed of fibrous part (fruit pulp and olive skin), pit, together containing approximately $5-8 \%$ of residual olive oil and water content between $25-70 \%$, depending on extraction systems [20,56-58].

The pomace generated per ton of processed olives is roughly 870 and $620 \mathrm{~kg}$ in the "two-phase" and "three-phase" systems, respectively [57] and the wet soft texture of the pomace restricts its transportation [20]. Pomace has an acidic $\mathrm{pH}(\approx 5.2)$, oil and fats $(8-14 \%)$ on dry matter basis and by elevated levels of phenolic substances $(1-3 \%$, on dry matter basis) $[8,59]$.

The pomace is sometimes used as animal feed [60] or composted to produce a stable organic soil amendment with fertilization value [60]. Pomace (Jift) is also used as a substrate for the production of activated carbon [61,62], as a source of bio-pesticides [63], in co-firing with coal at power stations [64] and as a source of residual oil for the soap industry [65]. Unused pomace if disposed improperly might cause serious environmental consequences [3]. Because of its organic content, this material can be used as a soil amendment after it has been treated, thus improving soil properties [13] leading to increased soil productivities [66].

The olive pomace calorific value largely exceeds that of other wood or agricultural biomass and releases considerable energy during its utilization. The olive pomace with heat energy of $23 \mathrm{MJ} / \mathrm{kg}$ [67-69] is considered a valuable resource of renewable energy and has become an alternative to natural gas and liquid fossil fuels normally used in house heating [70]. Many olive mills pressed the dried pomace to form blocks or briquettes and sell them to local communities as a fuel for home heating. Therefore, olive pomace has become a source of income for mills owners. Prior to 2000, small quantities of pomace (Jift) have been used for space heating at rural mills during winter. Currently, a majority of olive pomace produced in the region is upgraded by means of agglomeration, including briquetting and pelletizing [71,72].

Pelletizing is the process of compressing or molding crude or exhausted olive pomace into the shape of a pellet obtained by mechanical compression. The process starts with drying, grinding, conditioning, and pelletizing to be used later as upgraded solid fuel for space heating. Several alternatives for managing solid waste and wastewater streams generated by the olive oil industry were analyzed by Reference [73]. Pellets manufacturing for domestic water heating rank first for environmental benefits, while briquette manufacturing ranked second for use in domestic stoves for space heating [73].

Olive leaves and olive pomace can be composted to produce a high-quality soil fertilizer as demonstrated by many experiments conducted in pilot study and full-scale plants by Chowdhury et al., 2014 [74]. The produced compost has also low thermal conductivity less than $0.60 \mathrm{~W} / \mathrm{m}^{2} \mathrm{~K}$, therefore, can be used as cheap natural light weight fertilizer and good insulator to save energy in green roof buildings [75]. Important parameters that affects the composting process such as total pile volume, moisture content, particle size, porosity, nutritional balance, temperature, aeration, and $\mathrm{pH}$ have been extensively studied [76]. 


\subsection{Other Solid Byproducts}

A small amount of twigs and leaves are also generated at first step where the olives are washed and cleaned which account for $5 \%$ of the weight of the olives $[77,78]$. However, these byproducts can be used as low-cost fuel resource for heating and cooking in countryside in addition to animal feed. Olive leaves are also recognized as antioxidants resource of which can be extracted and sold to be used in herbal tea with anti-hypertensive, antioxidants, and diuretic effect [14]. Olive leaves antioxidants have also been assessed to determine their capacity for preventing oxidation of animal meat $[79,80]$.

\section{Olive Mill Waste Management Practices}

There are no exclusive solutions exist yet, but several options have been recommended for valorization of olive mill waste streams. Several factors are to be considered when selecting the best management practice. These include the quantity of waste to process, required investment in infrastructure, available land for application, agronomic benefits that follow and the local regulations. Many countries in the Mediterranean faces' desertification, therefore, the application of organic matter to agricultural soils is very popular and can help recover topsoil fertility and slow down soil erosion processes in hilly areas. In organic farming, the use of these natural byproducts represents a significant plant fertilizer value and contributes to close the residual resources cycle. Consequently, the use of olive mill by-product as fertilizers and soil amendments on olive orchards will preserve the olive trees ecosystem and contribute to sustainable agriculture.

\subsection{Characteristics, Treatment, Valorization and Utilization of OMWW}

The olive oil production in the Mediterranean region is around 2 million tons annually, resulting in approximately of 30 million $\mathrm{m}^{3}$ of OMWW and 20 million tons of olive pomace [76]. Oil mill wastewater $(\mathrm{OMWW})$ has reddish-black color because of the existence of high concentration of phenolic compounds $(10,650 \mathrm{mg} / \mathrm{L})$, a strong unpleasant odor, a high concentration of fats, oil and grease (FOG) of $(10,650 \mathrm{mg} / \mathrm{L})$ and an extremely high organic load (COD and $\left.\mathrm{BOD}_{5}\right)$ [13]. This organic load is approximately 400 times higher than that of typical domestic wastewaters [13]. Additionally, OMWW is acidic (pH 4 to 5), has an electrical conductivity (EC) ranging between 5.5 and $12.0 \mathrm{dS} / \mathrm{m}$ and a high concentration of polyphenols $[9,10]$.

Quantities of byproducts generated, and their characteristic are a function of the extraction method used $[4,5,29]$. Characteristics of OMWW and pomace from a 3-phase extraction process are presented in Table 2. The chemical characteristics of OMWW prevents their direct discharge into domestic wastewater treatment plants $[15,81,82]$. If applied to soils or disposed in Wadis (water streams) without proper treatment, OMWW can cause serious environmental problems. Land application of OMWW has been widely used because of its valuable plant nutrients (nitrogen, phosphate, potassium, iron and magnesium) and high organic content $[14,83,84]$; even though some chemical components in OMWW might result in soil and water pollution, in addition to the risk of phytotoxicity [85-88].

The addition of OMWW and pomace to agriculture land might increase land yield by increasing soil organic matter and by providing valuable nutrients such as (nitrogen, phosphate and potassium) as demonstrated by several studies [10,37-39,56,58,89-92]. This is very important for most soils in the Mediterranean agricultural lands, which have deficiencies in soil nutrients and organic matter [37,57,93]. The organic content of OMWs can improve the structure of soil aggregates and, consequently increase soil porosity and water retention capacity $[94,95]$. However, an incorrect application of OMWs might result in reduction of crop yield due to temporary immobilization of mineral nitrogen [57]. 
Table 2. Chemical Composition of oil mill wastewater (OMWW), Pomace and Composts [8].

\begin{tabular}{cccc}
\hline Parameters & OMMW & Wet Olive Pomace & Composts \\
\hline $\mathrm{pH}$ & $4-6$ & $5-7$ & $50-10$ \\
Dry matter $(\%)$ & $6-7$ & $50-71$ & \\
Water $(\%)$ & 83 & 70 & \\
$\mathrm{BOD}(\mathrm{g} / \mathrm{L})$ & $35-110$ & & \\
$\mathrm{COD}(\mathrm{g} / \mathrm{L})$ & $40-220$ & & $2-7.3$ \\
$\mathrm{EC}(\mathrm{dS} / \mathrm{m})$ & $5-12$ & $1-5$ & $260-900$ \\
Organic matter $(\mathrm{g} / \mathrm{kg})$ & $46-62$ & $840-980$ & $110-580$ \\
$\mathrm{TOC}(\mathrm{g} / \mathrm{kg})$ & $34-40$ & $490-540$ & $11-54$ \\
$\mathrm{TN}(\mathrm{g} / \mathrm{kg})$ & $0.60-2.10$ & $7-19$ & $9-36$ \\
$\mathrm{C} / \mathrm{N}$ & $52-54$ & $28-73$ & $1-30$ \\
$p(\mathrm{~g} / \mathrm{kg})$ & $0.15-0.30$ & $0.7-2.2$ & $6-44$ \\
$\mathrm{~K}(\mathrm{~g} / \mathrm{kg})$ & $2-9$ & $7-30$ & $2-41$ \\
$\mathrm{Na}(\mathrm{g} / \mathrm{kg})$ & $0.1-0.4$ & $0.5-1.6$ & $7-72$ \\
$\mathrm{Ca}(\mathrm{g} / \mathrm{kg})$ & $0.20-0.6$ & $1.5-9$ & $1-57$ \\
$\mathrm{Mg}(\mathrm{g} / \mathrm{kg})$ & $0.04-0.22$ & $0.7-4$ & $100-410$ \\
$\mathrm{Fe}(\mathrm{mg} / \mathrm{kg})$ & $18-120$ & $80-1470$ & $1.5-80$ \\
$\mathrm{Cu}(\mathrm{mg} / \mathrm{kg})$ & $1.5-6$ & $12-29$ & $13-130$ \\
$\mathrm{Mn}(\mathrm{mg} / \mathrm{kg})$ & $1-12$ & $5-39$ & $38-138$ \\
$\mathrm{Zn}(\mathrm{mg} / \mathrm{kg})$ & $2.4-12$ & $10-37$ & $0.1-4$ \\
$\mathrm{Phenols}(\%)$ & $1-11$ & $0.5-2.4$ &
\end{tabular}

OMWs spreading should be applied cautiously because the unstabilized organic matters might inhibit or reduce crops growth. This might be attributed to phenols, fatty acids, tannins and high $\mathrm{C} / \mathrm{N}$ ratio leading to a nitrogen competition between crop roots and soil microorganisms and roots anoxia because of oxygen consumption by microorganisms' $[11,19,20,95,96]$. The phytotoxic and antimicrobial impacts is primarily due to phenolic compounds ability to mix with other organic materials such as proteins, therefore changing the cell membrane permeability and intercellular transfer mechanisms [59]. At the same time, substantial amounts of organic compounds, potassium and phosphorous are added to the cultivated soils as organic fertilization [58].

Several studies have reported many advantages of rational use of OMWs as soil amendment without taking in their account potential dangers for crops and environment, on the other hand other studies showed negative effects on soil and surrounding environment mainly surface and ground water. These differences between these studies might be because of dissimilar experimental circumstances such as: soil type, cultural practices, methods of spreading, dosages used, crop phenological stage, climatic conditions and ground water depth. To avoid any problems a rational use of OMWs require proper application method and respecting regulations (if exist) [25,58].

\subsection{Potential Valorization Options for Olive Mill Wastewaters (OMWWs)}

Research is oriented toward flexible and efficient treatment of OMWW to degrade phenolic compounds and organic matter, to reduce its phytotoxicity and chemical oxygen demand [63]. OMWW management and treatment are facing many difficulties such as: high territorial scattering, seasonal operation, its high organic content, phenols and long chain fatty acids which are not easy biodegradable [97].

Treatment that could ensure solutions for the depollution of the waste, should compensate high capital investment and operation costs with the opportunity of recycling and recovering some valuable components. Many depolluting treatment technologies are existing; however, they require a high investment costs and a high level of technological know-how.

Further integrated approaches should be established combining minimization, recycling, treatment, valorization and energy generation measures to recover highly valued materials and reaching the safe limits of purified effluent to be reused later in irrigation, construction and industrial applications. 
One of these methods is the biorefinery approach [98], which makes olive oil production process environmentally friendly and the treatment cost effective.

Biorefineries include a wide range of technologies to separate main biomass components (lignin, carbohydrates, protein, etc.) and convert them into biofuels and chemicals. The approach has been applied to several biomasses and a broad spectrum of different large scale biorefineries using a single feedstock. Benchmark and sustainability study of OMWW treatment methods was performed by Reference [99], indicating that the most useful methods for reduction of organic compounds are photo-Fenton, electrolysis, membrane filtration and supercritical water oxidation. Reduced environmental impact was obtained by coagulation, anaerobic digestion and lime treatments. The lowest cost-effective processes are membrane filtration and composting because of the added value of antioxidant phenolic compounds recovered and composts material, respectively [100].

Numerous studies have shown that phenolic compounds have many biological properties such as: antioxidant, anti-inflammatory, anticarcinogenic, antimicrobial activities and free radical scavenging [100,101]. Olive oil by-products bioactive characteristics were assessed by Reference [102], the study reported a large variety of biological activities including the antiallergic activity of OMWW, antibacterial activity of leaves and flowers, in addition to the collagen production, therefore have the potential for more development to be used in pharmacies applications and skin care industry [102].

\subsection{OMWWs Treatment Methods}

The difficulties in installing a waste treatment facility to treat olive mill by-products are related to its high organic loads which is hard to biodegrade, seasonal operation of olive mills (October-January), regional scattering and the high treatments cost particularly for small-middle size enterprises. OMWW must be treated preceding its discharge to the environment. All known treatment methods used for industrial and domestic wastes treatment have been tested on OMWW but unfortunately none of them seemed completely appropriate to be implemented in OMWW treatment.

Many treatment approaches were tested for OMWW treatment, such as physical methods (filtration, ultrafiltration/reverse osmosis and evaporating ponds) [81]; chemical methods (electrolytic oxidation, Fenton oxidation, neutralization with lime and combustion); physiochemical methods (floatation, adsorption, sedimentation, settling, sand, membrane infiltration and coagulation-flocculation, ion exchange and electrocoagulation) and biological approaches (anaerobic or aerobic degradation, biofiltration, activated sludge, composting and lagooning or direct irrigation on soils) [81].

Physical and physicochemical treatment methods lack sustainability, while the biological methods are effective and viable but they are not appropriate due to slow degradation rates of OMWW that is, requires a longer lag phase. Some of the earlier proposed treatment methods are applied in real olive mills after laboratory investigations, unfortunately none of them was cost effective and technically feasible [103]. However, the use of a combination of these technologies has indicated a satisfactory result.

The application of biological methods (anaerobic/aerobic digestion and composting) could be a possible solution for treatment of OMWW, especially if the waste high toxicity is reduced first. This might be achieved with advanced oxidation processes (AOPs) [104]. AOPs are chemical treatment processes relies on highly reactive agents in the reactions, like hydroxyl radicals causing the destruction of the targeted contaminant [105]. AOPs technologies have been effectively used for strong industrial pollutants, such as pesticides, phenolic compounds, surfactants, coloring materials and in pharmaceuticals industries [106]. Normally, they are used as pre-treatment steps in biological treatment methods to reduce toxic organic compounds concentrations which slow down the biological activities [8].

Constructed wetlands are currently used to treat different wastewaters such as municipal, industrial and food-industrial [107-111] and recently has also been used for treatment of OMWW [112]. High organic contents of OMWW required employment of several pre-treatment stages such as coagulation [113], electrochemical oxidation [114] and biological trickling filters [110] which makes the 
constructed wetlands just a polishing treatment process. Some studies have reported high removal efficiency of organic matter (86-95\%) using free water surface wetland systems, however the organic surface loads were $\left(5-57 \mathrm{~g} / \mathrm{m}^{2} /\right.$ day) $[110,115]$. Constructed wetlands has other benefits such as low construction and operation costs mainly for systems which will operate for long times in addition to environmental and landscaping benefits [108-110,116]. However, constructed wetlands cannot be used everywhere because it is land-based process and need adequate space.

Unfortunately, complete reduction of OMWW pollutants cannot be obtained by applying single method. Many management alternatives have been developed for handling, treatment and valorization of OMWWs while reducing their environmental impacts. These methods are categorized as physical, chemical or biological treatment methods. None of them has been applied commercially since they have lacking sustainability in long-term basis [116]. Targeting the reduction of OMWW phytotoxicity, current methods used for treatment of OMWW are summarized below.

\subsubsection{Physical Methods}

Physical methods are normally used as a pre-treatment step to remove the enclosed solids particles.

\section{Evaporation}

The simplest and most economical wastewater management technique is the evaporation of water from storage ponds or lagoons. It is widely used method in the Mediterranean region where favorable warm climate conditions prevail, such as in Northern Africa, southern Europe and eastern Mediterranean countries. Lagoons are very simple and inexpensive, but risks of surrounding environment contamination exist (mainly soil and water) [57]. The process is very slow and requires large land areas; it can sometimes produce unpleasant odors as a result of the decomposition of organic materials and fermentation processes, attract insects and rodents and help their breeding, and groundwater contamination might occur if the lagoon is not properly sealed [11,59]. After solids settling, evaporation of OMWW produces a sludge rich in residual oil and organic matter, which can be used as a renewable energy resource instead of fuel for heating. Several studies recommended OMWW composting as a solution for this waste [11]. Lagooning is rapidly disappearing, so the transport of OMWW and olive pomace must be handled with suitable methods of transportation to avoid any leaks or sanitary incidents.

\section{Direct Application to Soil}

Several scholars have tested direct application of OMWW to soils as an organic fertilizer and analyzed its positive and negative impacts on soils. Advantages are linked to its elevated nutrients content, mainly potassium; while, negative impacts are attributed to its salt content (measured as electrical conductivity), low $\mathrm{pH}$ and inherent phytotoxicity caused by polyphenols [116]. Some organic compounds mobility in soils can be reduced by OMWW application on agriculture land. Its use was recommended to reduce the leaching of herbicides (clopyralid and metamitron) in cultivated lands as reported by Reference [117]. Also, its high anti-microbial capability may be beneficial in sanitizing the soil against some plant pathogens such as (Rhizoctonia Solani) as confirmed by Reference [117].

\subsection{Physical-Chemical Treatment}

Physicochemical methods are relatively cheap but they cannot eliminate the pollution load of OMWW completely. In these processes, chemicals are added to create electro-coagulation, precipitation and destruction of dissolved organic compounds. Calcium hydroxide, aluminum sulphate and lime pre-treatment are used to decrease pollution from OMWW because lime is available at lower cost compared to other chemicals [118]. Another approach applied by several mills is the Electro Osmosis Dewatering (EOD) method, which involves placing a colloidal material between two electrodes to extract water from OMWW. Sodium chloride was found to be a very effective electrolyte for use in the EOD technique [119]. Applied electro-coagulation using coupled iron aluminum 
electrodes accompanied with ozonation for treatment of OMWW treatment resulted in removal COD and TSS at $47.6 \%$ and $82.6 \%$, respectively [120]. Additionally, they observed significant elimination of the high levels of organic compounds after 70 min of treatment. Srikanth et al., 2019 [121] used integrated purification of OMWW through pre-treatments using chitosan and alum coagulants and biological methods. They reported removal efficiencies of $57.2 \%$ and $62.9 \%$ for COD and phenols, respectively using Alum as coagulants which appears to be the best from technical and economical point of view with treatment cost of $5.86 € . \mathrm{m}^{-3}$.

\section{Biotechnological Treatments of OMMW}

Biological treatments, such as aerobic and anaerobic methods used microorganisms to degrade the complex organic material of OMWW and considered the most environmentally friendly approach. Aerobic methods have higher removal efficiency than anaerobic; but aerobic method required continues mechanical aeration which make the process costly $[122,123]$. However, these methods are sensitive to toxic substances that hardly biodegradable like polyphenols [123] which reduce the efficiency of these methods. However, in terms of economics and feasibility, these treatment methods have not yet been commercially available for small scale enterprises.

\subsection{Aerobic Treatments}

Aerobic treatment in the presence of natural occurring microorganisms (such as fungi, protozoa, bacteria and other microbes) is an effective method for treatment of OMWW to reduce its pollution. In aerobic processes, oxygen is provided either by agitating the reactor or by supplying air by compressor. It is based on targeting the degradation of phenolic compounds, the major contributor to phytotoxicity. These options are scientifically appealing; however, they are not widely used commercially possibly because of cost considerations [10]. The aerobic method cannot detoxify OMWW inhibitory compounds such as polyphenols and lipids [124]. The capital investments in aerobic methods are lower than anaerobic methods but the running costs are significantly higher due to the need of continuous air supply.

\subsection{Composting and Cocomposting of OMWs to Produce Soil Amendments}

Composting is nature's way of recycling, it biodegrades organic wastes, such as crop residues, leaves, grass trimmings, wood, food waste, cartons, feathers and turning them to a valuable organic fertilizer. Composting is natural biological process where various microorganisms break organic matter down into simpler substances under controlled aerobic conditions. Composting of organic materials is a recovery system to produce high-quality organic amendments to be used in agricultural land to replace animal manure or chemical fertilizers application to intensive crop cultivations and the peat moss in nursery [11].

Composting is the primary choice for management of OMWs to convert it to fertilizer, thus returning nutrients to agricultural soils. Composting also reduces harmful effects of nutrient overloading or phytotoxicity noticed when spreading untreated OMWW directly into agricultural land. Being a liquid, the OMWW must absorbed by a firm substrate such as lignocellulosic matrix before proceeding to the composting process. Literature review showed that compost obtained from OMWs is of exceptional quality $[76,125,126]$.

Composting has gained momentum over the past few decades as soil amendments because agricultural soils continue to lose their fertility and the use of soil amendments is needed to replenish organic material and nutrient content. Compost fulfils these needs at affordable prices, too. Additionally, compost can improve soil water capacity, cation exchange, increase microbial activity and reduce pesticide numbers [127]. 


\subsection{Anaerobic Digestion}

Anaerobic treatment of OMWW results in the conversion of organic matter to biogas (a mixture of methane and carbon dioxide, with other trace gases) that has significant energy value [125]. Residual solids and treated OMWW has value as a soil amendment, the potential use of OMWW in agriculture is one of the main goals of anaerobic digestion. The primary bottleneck in this process is the methanogenic bacteria inhibition by the presence of organic acids and phenolic compounds in the OMWW [7]. A pretreatment stage to remove undesirable compounds was recommended to be used prior to initiating the up flow anaerobic sludge blanket (UASB) treatment system [30]. Also, Filidei et al. (2003) suggested pretreatment by sedimentation and filtration preceding anaerobic digestion as a practical approach for OMWW treatment [127]. Ammary (2005) used anaerobic sequencing batch reactors (ASBR) for OMWW treatment and reported an 83\% reduction of COD [128]. Furthermore, another researcher used an UASB reactor for OMWW treatment and reported COD removal in the range $75-85 \%$, at 5 days of Hydraulic Retention Time (HRT) and influent COD concentration of $40 \mathrm{~g} / \mathrm{L}$ [129]. Khatib et al., (2009) used an UASB reactor and achieved COD removal between $46-84 \%$ and organic load reduction from $27 \mathrm{~g} / \mathrm{L}$ to less than $5 \mathrm{~g} / \mathrm{L}$ [130] which permits the treated OMMW to be discharged to municipal wastewater treatment plants.

\subsection{Biophysical and Biochemical Treatments Options}

A combined aerobic biodegradation followed by ultrasonic irradiation treatment was used for the reduction of toxic phenolic compounds in OMWW [131]. They reported $81 \%$ degradation of total phenols and $80 \%$ reduction in influent COD when OMWW was exposed to an ultrasonic field for $90 \mathrm{~min}$. Advanced oxidation with ozone $\left(\mathrm{O}_{3}\right)$, aerobic biodegradation and photo-degradation by UV radiation for COD elimination were reported by Reference [122]. They observed removal of $91 \%$ of influent COD in biological and $\mathrm{UV} / \mathrm{O}_{3}$ treatment on pretreated OMWW.

\section{Valorization Options for Two-Phase Olive Mill Waste}

The two-phase olive mills reduce water consumption and produce only wet pomace with high moisture content $(65 \%)$ called "alperujo" in Spain. The material is stench and has fluffy texture that makes its handling and transportation not easy [20,48]. Its management requires special measures such as: storage tanks equipped with drainage valves, pump and septic container [11].

\subsection{Physical Chemical Treatments-Second Extraction of Oil after Drying}

It is possible to obtain olive oil residue from alperujo by further extraction with solvents after drying process but the high moisture content of the alperujo requires high energy input and causes some technical problems. The high cost of the drying process because of greater energy requirement in addition to lower demand for second extraction oil has led researchers to consider unconventional techniques for its extraction [8].

\subsection{Potential Thermal Energy}

Thermal or electric energy by combustion of exhausted olive cake after the second extraction is generally used as fuel in husk mills [132]. Presently dried husk combustion is applied in majority of the mills because it contains reasonable high calorific value $(23 \mathrm{MJ} / \mathrm{kg})$ [7]. Two different potential energy recovery alternatives of the solid and liquid residues delivered by the olive oil industry. The first one is the upgrading of olive oil industry solid waste through pelletizing, briquetting and torrefaction; and the thermochemical conversion of olive oil industry residues, through pyrolysis and gasification (thermochemical routes) [132]. 


\subsection{Direct Application to Soil}

Alperujo has been applied directly to near agricultural lands as soil amendment because of its elevated potassium content and therefore no transportation is required. Even its toxicity is less than OMWW; it might cause some imbalances in soil nutrition as shown by several studies, because of its high $\mathrm{C} / \mathrm{N}$ ratio which modifies the nitrogen cycle especially for acidic soils [133,134].

\subsection{Biotechnological Treatments}

\subsubsection{Anaerobic Treatment}

Biogas production and partially stabilized organic substance are obtained during anaerobic process [10]. Biogas can be used for energy generation of and the organic substance can be used as soil amendment. It is estimated that methane production from olive husk biogas reached $75-80 \%$ [135].

\subsubsection{Solid Fermentation}

Alperujo has been also used in livestock nutrition but because of its low proteins content, it is advice to add protein supplement to the livestock feed [136]. Solid fermentation also improved nutritional properties as reported by Reference [61]. They found and increase in protein percentage in olive husk between $6-40 \%$ by the solid fermentation treatment. Started by microorganisms in the solid medium, the process has been applied successfully for animal feeds, enzymes and fuel production.

\subsubsection{Composting}

Due to its semisolid consistency, several researchers recommended the co-composting of a mixture of alperujo with other agricultural wastes such as straw, sawdust and bark chips as bulking agents before composting. The ending product contained substantial amounts of mineral nutrients, no phototoxic effects and good humification. The composting can be considered as affordable approach to recycle of olive oil byproducts, which represent a good alternative to combustion. It is recommended to compost it with available manure in the neighboring areas around the olive mills [137].

\subsection{Valuable Products Extraction}

Cardoso et al., (2003) reported positive results in studying the economic feasibility of pectin's extraction from alperujo, which might be considered as cheap substrate for the extraction of important compound such as pectin's [138]. These compounds are usually used as stabilizers, gelling factors and emulsifiers in food industries [11], therefore a new strong source of pectin, using agricultural wastes as raw materials. It is reported also that alperujo is excellent source of phenols with different biological behaviors. Obied et al. (2005) reported that total phenols reached $98 \%$ in olive mill waste [139]. Tyrosol, hydroxytyrosol, caffeic acid, oleocanthal and oleuropein are the main phenolic compounds [140] found in OMWW that can be used in the pharmaceutical industry. Many scientific researches confirmed the antioxidant, cardio protective, anti-microbial, anti-hypertensive and anti-carcinogenic behavior of these components, which might be entered in cosmetic, pharmaceutical and food productions. New technologies have been emerged to improve extraction of these compounds [141].

\section{Additional Valorization Options}

Many very interesting but not widespread ways of valorization the olive mill waste have been developed. For example, Pagnanelli et al. [141] recommended its usage as a heavy metal sorbent substance in aqueous solutions treatment. It is applied to agricultural lands to strengthen and extend sorption of insecticides (imidacloprid) and herbicides (simazine), thus reducing their biodegradation, slow down their leaching which reduces groundwater pollution risk [140,141].

A new material for the manufacturing of containers by recycling and mixing alperujo with thermoplastic polymers was studied by Reference [141]. A comprehensive approach for recycling 
olive pressing byproducts was proposed by Reference [115]. Many Marketable compounds can be extracted which are valuable in pharmaceutical and cosmetic industries. Purification of wastewater and solid residues composting are also included in this integrated approach which can be used in olive orchard fertigation.

\section{Conclusions}

In this study the current management's methods for olive mill wastes and treatment methods and techniques applied for the management of olive mill wastewater and solid waste in major oil producing countries were investigated. Due to favoring warm weather conditions and large open areas in the MENA region, liquid waste disposed in evaporations lagoons equipped with suitable mitigation measures such as rubber lining to prevent any leakage to ground water and alleviate any environmental impacts is recommended for OMMW pretreatment followed by constructed wetland treatment which are financially affordable by mill owners.

Centralized treatment plants are considered more suitable to treat OMWW, but it is accompanied with extra high transportation costs. Also, the olive mills are geographically scattered around country sides, which put some difficulties on building centralized large-scale treatment plants or management systems. Byproducts streams have potential economic value that remains to be utilized such as fertilizers after pretreatment and composting. Appropriate legislation is required to control application rate of untreated OMWW to the agricultural lands. Also, olive pomace is a valuable renewable energy source with an energy density of $23 \mathrm{MJ} / \mathrm{kg}$ and has become an inexpensive alternative for fossil fuels which used for home heating in country sides.

The solution to the OMWW disposal problems needs full cooperation of all partners involved in olive oil processing industry and consolidate their efforts. Two phase system should be adopted to minimize OMWW generation from the three phase systems. National planning is needed to implement a master plan for OMWW management on the ground. This will be accomplished by connecting all stakeholders through planning, research, regulatory, institutional, financial, and technical means. The key factors for successful of OMWW management require a suitable legislations, proper inspection, enforcement, and proper disposal and treatment facilities. An integration of these alternatives, with law enforcement support, will help solve issues with olive mill waste (OMWW) management in the region.

Author Contributions: Conceptualization, K.A. and G.A.-R.; Methodology, K.A. and G.A.-R.; Software, G.A.-R.; Formal analysis, K.A and G.A.-R.; Investigation, K.A. and G.A.-R.; Resources, K.A. and G.A.-R.; Data curation, K.A. and G.A.-R.; Writing-Original draft preparation, K.A. and G.A.-R.; Writing-Review and editing, K.A. and G.A.-R.; Visualization, G.A.-R.; Supervision, G.A.-R.; Funding acquisition, K.A. and G.A.-R. All authors have read and agreed to the published version of the manuscript.

Funding: The Deanship of Scientific Research (DSR), King Abdulaziz University, Jeddah, Saudi Arabia under grant no. G-658-135-1441. The authors, therefore, acknowledge with thanks DSR technical and financial support.

Acknowledgments: This project was funded by the Deanship of Scientific Research (DSR), King Abdulaziz University, Jeddah, Saudi Arabia under grant no. G-658-135-1441. The authors, therefore, acknowledge with thanks DSR technical and financial support. For research articles with several authors, a short paragraph specifying their individual contributions must be provided: Software, K.I; Validation, X.X., Y.Y. and Z.Z.; Visualization, K.I.; Supervision, K.I.; Project administration, X.X.

Conflicts of Interest: The authors declare no conflict of interest.

\section{References}

1. Galanakis, C.M. Olive Mill Waste Recent Advances for Sustainable Management; Academic Press: London, UK, 2017; pp. 1-3.

2. FAOSTAT. Food and Agriculture Organisation Database. 2015. Available online: http://www.fao.org/home/ search/en/?q=Olive\%20mill\%20wastes\%20production (accessed on 4 April 2020).

3. Khdair, I.A.; Abu-Rumman, G. Pollution Estimation from olive wastewater in Jordan. Heliyon 2019, 5, e02386. [CrossRef] [PubMed] 
4. Khdair, I.A.; Abu-Rumman, G. Evaluation of the environmental pollution from olive mills wastewater. Fresen. Environ. Bull. 2017, 26, 2537-2540.

5. Ntougias, S.; Gaitis, F.; Katsaris, P.; Skoulika, S.; Iliopoulos, N.; Zervakis, G.I. The effects of olives harvest period and production year on olive mill wastewater properties-evaluation of Pleurotus strains as bioindicators of the effluent's toxicity. Chemosphere 2013, 92, 399-405. [CrossRef] [PubMed]

6. Ouzounidou, G.; Zervakis, G.I.; Gaitis, F. Raw and microbiologically detoxified olive mill waste and their impact on plant growth. Terr. Aquat. Environ. Toxicol. 2010, 4, 21-38.

7. Morillo, J.A.; Antizar-Ladislao, B.; Monteoliva-Sanchez, M.; Ramos-Cormenzana, A.; Russell, N.J. Bioremediation and biovalorisation of olive-mill wastes. Appl. Microbiol. Biotechnol. 2009, 82, 25-39. [CrossRef] [PubMed]

8. Alburquerque, J.A.; Gonzalvez, J.; Garcia, D.; Cegarra, J. Agrochemical characterization of "alperujo", a solid by-product of the two phase centrifugation. Bioresour. Technol. 2004, 91, 195-200. [CrossRef]

9. Alburquerque, J.A.; Gonzalvez, J.; Garcia, D.; Cegarra, J. Effects of a compost made from the solid byproduct (alperujo) of the two-phase centrifugation system for olive oil extraction and cotton gin waste on growth and nutrient content of ryegrass (Lolium perenne L.). Bioresour. Technol. 2007, 98, 940-945. [CrossRef]

10. Paraskeva, P.; Diamadopoulos, E. Technologies for olive mill wastewater (OMW) treatment: A review. J. Chem. Technol. Biotechnol. 2006, 81, 1475-1485. [CrossRef]

11. Roig, A.; Cayuela, M.L.; Sanchez-Monedero, M.A. An overview on olive mill wastes and their valorization methods. Waste Manag. 2006, 26, 960-969. [CrossRef]

12. Galanakis, C.M. Recovery of high added-value components from food wastes: Conventional, emerging technologies and commercialized applications. Trends Food Sci. Technol. 2012, 26, 68-87. [CrossRef]

13. Niaounakis, M.; Halvadakis, C.P. Olive Mill Waste Management. Literature Review and Patent Survey, 2nd ed.; Elsevier: London, UK, 2006.

14. Ayoub, S.; Al-Absi, K.; Al-Shdiefat, S.; Al-Majali, D.; Hijazean, D. Effect of olive mill wastewater land-spreading on soil properties, olive tree performance and oil quality. Sci. Hortic. 2014, 175, 160-166. [CrossRef]

15. Rusan, M.; Albalasmeh, A.; Zuraiqi, S.; Bashabsheh, M. Evaluation of phytotoxicity effect of olive mill wastewater treated by different technologies on seed germination of barley (Hordeum vulgare L.). Environ. Sci. Pollut. 2015, 22, 9127-9135. [CrossRef] [PubMed]

16. Rusan, M.J.; Malkawi, H.I. Dilution of olive mill wastewater (OMW) eliminates its phytotoxicity and enhances plant growth and soil fertility. Desalin. Water Treat. 2016, 57, 27945-27953. [CrossRef]

17. Wahsha, M.; Bini, C.; Nadimi-Goki, M. The impact of olive mill wastewater on the physicochemical and biological properties of soils in northwest Jordan. Environ. Qual. 2014, 15, 25-31.

18. Rigane, H.; Chtourou, M.; Mahmoud, I.B.; Medhioub, K.; Ammar, E. Polyphenolic compounds progress during olive mill wastewater sludge and poultry manure co-composting, and humic substances building (Southeastern Tunisia). Waste Manag. Res. 2015, 33, 73-80. [CrossRef]

19. Barbera, A.C.; Maucieri, C.; Cavallaro, V.; Ioppolo, A.; Spagna, G. Effects of spreading olive mill wastewater on soil properties and crops, a review. Agric. Water Manag. 2013, 119, 43-53. [CrossRef]

20. Suzzi, G.; Tofalo, R. Trattamento dei reflui. In Collana Coltura \& Cultura-L'ulivo e l'olio; Pisante, M., Inglese, P., Lercker, G., Eds.; Bayer Crop Science: Bologna, Italy, 2009; pp. 690-695.

21. Boubaker, F.; Ridha, B.C. Anaerobic co-digestion of olive mill wastewater with olive mill solid waste in a tubular digester at mesophilic temperature. Bioresour. Technol. 2007, 98, 769-774. [CrossRef]

22. Kapellakis, I.E.; Tsagarakis, K.P.; Avramaki, C.; Angelakis, A.N. Olive mill wastewater management in river basins: A case study in Greece. Agric. Water Manag. 2006, 82, 354-370. [CrossRef]

23. El Hadrami, M.; Belaqziz, M.; El Hassni, S.; Hanifi, A.; Abbad, R.; Capasso, L.; Gianfreda, I. Physicochemical characterization and effects of olive oil mill wastewaters fertirrigation on the growth of some Mediterranean crops. J. Agron. 2004, 3, 247-254.

24. Di Bene, C.; Pellegrino, E.; Debolini, M.; Silvestri, N.; Bonari, E. Short- and long-term effects of olive mill wastewater land spreading on soil chemical and biological properties. Soil Biol. Biochem. 2013, 56, 21-30. [CrossRef]

25. Belaqziz, M.; El-Abbassi, A.; Lakhal, E.K.; Agrafioti, E.; Galanakis, C.M. Agronomic application of olive mill wastewater: Effects on maize production and soil properties. J. Environ. Manag. 2016, 171, 158-165. [CrossRef] 
26. Sierra, J.; Marti, E.; Garau, A.M.; Cruanas, R. Effects of the agronomic use of olive oil mill wastewater: Field experiment. Sci. Total Environ. 2007, 378, 90-94. [CrossRef]

27. Torres, M.M.; Maestri, D.M. The effects of genotype and extraction methods on chemical composition of virgin olive oils from Traslasierra Valley (Cordoba, Argentina). Food Chem. 2006, 96, 507-511. [CrossRef]

28. Brunetti, G.; Plaza, C.; Senesi, N. Olive pomace amendment in Mediterranean conditions: Effect on soil and humic acid properties and wheat (Triticum turgidum L.). J. Agric. Food Chem. 2005, 53, 6730-6737. [CrossRef]

29. Azbar, N.; Bayram, A.; Filibeli, A.; Muezzinoglu, A.; Sengul, F.; Ozer, A. A Review of waste management options in olive oil production. Crit. Rev. Environ.Sci. Tec. 2004, 34, 209-247. [CrossRef]

30. Caputo, A.C.; Scacchia, F.; Pelagagge, P.M. Disposal of by-products in olive oil industry: Waste-to-energy solutions. Appl. Therm. Eng. 2003, 23, 197-214. [CrossRef]

31. Obied, H.K.; Allen, M.S.; Bedgood, D.R.; Prenzler, P.D.; Robards, K.; Stockmann, R. Bioactivity and analysis of biophenols recovered from olive mill waste. J. Agric. Food Chem. 2005, 53, 823-837. [CrossRef]

32. Galanakis, C.M.; Tornberg, E.; Gekas, V. The effect of heat processing on the functional properties of pectin contained in olive mill wastewater. LWT Food Sci. Technol. 2010, 43, 1001-1008. [CrossRef]

33. Rahmanian, N.; Jafari, S.; Galanakis, C. Recovery and removal of phenolic compounds from olive mill wastewater. J. Am. Oil Chem. Soc. 2014, 91,1-18. [CrossRef]

34. Jarboui, R.; Sellami, F.; Kharroubi, A.; Gharsallah, N.; Ammar, E. Olive mill wastewater stabilization in open-air ponds: Impact on clay-sandy soil. Bioresour. Technol. 2008, 99, 7699-7708. [CrossRef]

35. Borja, R.; Sanchez, E.; Raposo, F.; Rincon, B.; Jimenez, A.M.; Martin, A. Study of the natural biodegradation of two-phase olive mill solid waste during its storage in an evaporation pond. Waste Manag. 2006, 26, 477-486. [CrossRef]

36. Rinaldi, M.; Rana, G.; Introna, M. Olive-mill wastewater spreading in southern: Effects on a durum wheat crop. Field Crops Res. 2003, 84, 319-326. [CrossRef]

37. Lessage-Meessen, L.; Navarro, D.; Maunier, S.; Sigoillot, J.C.; Lorquin, J.; Delattre, M.; Simon, J.L.; Asther, M.; Labat, M. Simple phenolic content in olive oil residues as a function of extraction systems. Food Chem. 2001, 75, 501-507. [CrossRef]

38. Mulinacci, N.; Romani, A.; Galardi, C.; Pinelli, P.; Giaccherini, C.; Vincieri, F.F. Polyphenolic content in olive oil waste waters and related olive samples. J. Agric. Food Chem. 2001, 49, 3509-3514. [CrossRef]

39. Sierra, J.; Marti, E.; Montserrat, G.; Cruanas, R.; Garau, M.A. Characterisation and evolution of a soil affected by olive oil mill wastewater disposal. Sci. Total Environ. 2001, 279, 207-214. [CrossRef]

40. Azzam, M.; Al-Gharabli, S.; Al-Harahsheh, M. Olive mills wastewater treatment using local natural Jordanian clay. Desalin. Water Treat. 2015, 53, 627-636. [CrossRef]

41. Ilarioni, L.; Proietti, P. Olive tree cultivars. In The Extra-Virgin Olive Oil Handbook; Peri, C., Ed.; John Wiley \& Sons, Ltd.: Oxford, UK, 2014; pp. 59-67.

42. Nasini, L.; Proietti, P. Olive harvesting. In The Extra-Virgin Olive Oil Handbook; Peri, C., Ed.; John Wiley \& Sons, Ltd.: Oxford, UK, 2014; pp. 89-105.

43. Aviani, I.; Raviv, M.; Hadar, Y.; Saadi, I.; Dag, A.; Ben-Gal, A.; Yermiyahu, U.; Zipori, I.; Laor, Y. Effects of harvest date, irrigation level, cultivar type and fruit water content on olive mill wastewater generated by a laboratory scale 'Abencor' milling system. Bioresour. Technol. 2012, 107, 87-96. [CrossRef]

44. Kavvadias, V.; Doula, M.K.; Komnistsas, K.; Liakopoulou, N. Disposal of olive oil mill wastes in evaporation ponds: Effects on soil properties. J. Hazard. Mater. 2010, 182, 144-155. [CrossRef]

45. Ammar, E.; Nasri, M.; Medhioub, K. Isolation of Enterobacteria able to degrade simple aromatic compounds from the wastewater of olive oil extraction. World J. Microbiol. Biotechnol. 2005, 21, 253-259. [CrossRef]

46. Stasinakis, A.S.; Elia, I.; Petalas, A.V.; Halvadakis, C.P. Removal of total phenols from olive-mill wastewater using an agricultural byproduct olive pomace. J. Hazard. Mater. 2008, 160, 408-413. [CrossRef]

47. Paredes, C.; Cegarra, J.; Roig, A.; Sanchez-Monedero, M.A.; Bernal, M.P. Characterization of olive mill wastewater (alpechin) and its sludge for agricultural purpose. Bioresour. Technol. 1999, 67, 111-116. [CrossRef]

48. Davies, L.C.; Vilhena, A.M.; Novais, J.M.; Martins-Dias, S. Olive mill wastewater characteristics: Modelling and statistical analysis. Grasas Aceites. 2004, 55, 233-241. [CrossRef]

49. Hachicha, S.; Cegarra, J.; Sellami, F.; Hachicha, R.; Drira, N.; Medhioub, K.; Ammar, E. Elimination of polyphenols toxicity from olive mill wastewater sludge by its co-composting with sesame bark. J. Hazard. Mater. 2009, 161, 1131-1139. [CrossRef] [PubMed] 
50. Dermeche, S.; Nadour, M.; Larroche, C.; Moulti-Mati, F.; Michaud, P. Olive mill wastes: Biochemical characterizations and valorization strategies. Process. Biochem. 2013, 48, 1532-1552. [CrossRef]

51. Valta, K.; Aggeli, E.; Papadaskalopoulou, C.; Panaretou, V.; Sotiropoulos, A.; Malamis, D.; Moustakas, K.; Haralambous, K.J. Adding value to olive oil production through waste and wastewater treatment and valorisation: The case of Greece. Waste Biomass Valor. 2015, 6, 913-925. [CrossRef]

52. Della Greca, M.; Monaco, P.; Pinto, G.; Pollio, A.; Previtera, L.; Temussi, F. Phytotoxicity of low-molecular weight phenols from olive mill waste waters. Bull. Environ. Contamin. Toxicol. 2001, 67, 0352-0359. [CrossRef]

53. Pierantozzi, P.; Zampini, C.; Torres, M.; Isla, M.I.; Verdenelli, R.A.; Meriles, J.M.; Maestri, D. Physicochemical and toxicological assessment of liquid wastes from olive processing-related industries. J. Sci. Food Agric. 2012, 92, 216-223. [CrossRef]

54. Piotrowska, A.; Iamarino, G.; Rao, M.A.; Gianfreda, L. Short-term effects of olive mill waste water (OMW) on chemical and biochemical properties of a semiarid Mediterranean soil. Soil Biol. Biochem. 2006, 38, 600-610. [CrossRef]

55. Toscano, P.; Montemurro, F. Olive Mill By-Products Management. In Olive Germplasm-The Olive Cultivation, Table Olive and Olive Oil Industry in Italy; Muzzalupo, I., Ed.; InTech: London, UK, 2012; pp. 173-200.

56. Amirante, P. I sottoprodotti della filiera olivicola-olearia. In Olea, Trattato Di Olivicoltura; Fiorino, P., Ed.; Edagricole: Bologna, Italy, 2003; pp. 291-303.

57. Peri, C.; Proietti, P. Olive mill waste and by-products. In The Extra-Virgin Olive Oil Handbook; Peri, C., Ed.; John Wiley \& Sons, Ltd.: Oxford, UK, 2014; pp. 283-302.

58. Mechri, B.; Cheheb, H.; Boussadia, O.; Attia, F.; Ben Mariem, F.; Braham, M.; Hammami, M. Effects of agronomic application of olive mill wastewater in a field of olive trees on carbohydrate profiles, chlorophyll a fluorescence and mineral nutrient content. Environ. Exp. Bot. 2011, 71, 184-191. [CrossRef]

59. Haddadin, M.S.; Abdulrahim, S.M. Solid State Fermentation of Waste Pomace from Olive Processing. J. Chem. Technol. Biot. 1999, 74, 613-618. [CrossRef]

60. Haddadin, M.S.; Haddadin, J.; Arabiyat, O.I.; Hattar, B. Biological Conversion of Olive Pomace into Compost by Using Trichoderma Harzianum and Phanerochaete Chrysosporium. Bioresour. Technol. 2009, 100, 4773-4782. [CrossRef] [PubMed]

61. Mameri, N.; Aioueche, F.; Belhocine, D.; Grib, H.; Lounici, H.; Piron, D.L. Preparation of Activated Carbon from Olive Mill Solid Residue. J. Chem. Technol. Biot. 2000, 75, 625-631. [CrossRef]

62. El-Sheikh, A.H.; Newman, A.P.; Al-Daffaee, H.K.; Phull, S.; Cresswell, N. Characterization of activated carbon prepared from a single cultivar of Jordanian Olive stones by chemical and physicochemical techniques. J. Anal. Appl. Pyrol. 2004, 71, 151-164. [CrossRef]

63. Cayuela, M.L.; Millner, P.D.; Meyer, S.L.; Roig, A. Potential of Olive Mill Waste and Compost as Bio-Based Pesticides against Weeds, Fungi, and Nematodes. Sci. Total Environ. 2008, 399, 8-11. [CrossRef] [PubMed]

64. Cliffe, K.R.; Patumsawad, S. Co-Combustion of Waste from Olive Oil Production with Coal in a Fluidized Bed. Waste Manag. 2001, 21, 49-53. [CrossRef]

65. Fisher, D. Types of Olive Oil for Soap Making Recipes. 2013. Available online: http://candleandsoap.about. com/od/soapmakingoils/a/Types-Of-Olive-Oil-For-Soap-Making-Recipes.html (accessed on 10 March 2020).

66. Abu Khayer, M.; Cowdhury, M.B.; Akratos, C.S.; Vayenas, D.V.; Pavlou, S. Olive mill waste composting: A review. Int. Biodeter. Biodegr. 2013, 85, 108-119.

67. Tawarah, K.M.; Rababah, R.A. Characterization of Some Jordanian Crude and Exhausted Olive Pomace Samples. Green Sustain. Chem. 2013, 3, 146-162. [CrossRef]

68. Abu-Rumman, G.; Khdair, I.A.; Khdair, I.S. Current Status and Future investment Potential in Renewable Energy in Jordan: An overview. Heliyon 2020, 6, e03346. [CrossRef]

69. Al-Ananzeh, N.; Shakatreh, S.; Al-Ajlouni, K.; Al-Bsoul, A.; Chiha, M. Characterization and Thermal Analysis of Olive Mills Solid Residues (Peat, Pit, and Pulp) in Jordan: Case Study: Irbid, Ajloun, Jarash, and Jordan Valley. Energy Sources Part. A Recovery Util. Environ. Eff. 2016, 38, 1805-1811. [CrossRef]

70. Klemm, M.; Schmersahl, R.; Kirsten, C.; Weller, N. Biofuels Biofuel: Upgraded New Solids Biofuel Upgraded New Solids; Renewable Energy Systems Springer: New York, NY, USA, 2013; pp. 138-160.

71. El Hanandeh, A. Energy recovery alternatives for the sustainable management of olive oil industry waste in Australia: Life cycle assessment. J. Clean. Prod. 2015, 91, 78-88. [CrossRef] 
72. Chowdhury, A.K.M.M.B.; Michailides, M.K.; Akratos, C.S.; Tekerlekopoulou, A.G.; Pavlou, S.; Vayenas, D.V. Composting of three phase olive mill solid waste using different bulking agents. Int. Biodeterior. Biodegradation. 2014, 91, 66-73. [CrossRef]

73. Khdair, I.A.; Abu-Rumman, G.; Khdair, I.S. Thermal Conductivity of Olive Cake Compost (OCC) as affected by Moisture and Density: An Experimental and Mathematical Modeling. Compost Sci. Util. 2020, 6, 1-8. [CrossRef]

74. Chowdhury, A.K.M.M.B.; Akratos, C.S.; Vayenas, D.V.; Pavlou, S. Olive mill waste composting: A review. Int. Biodeterior. Biodegrad. 2013, 85, 108-119. [CrossRef]

75. Fokaides, P.A.; Polycarpou, P. Exploitation of Olive Solid Waste for Energy Purposes. Renewable Energy, Economies, Emerging Technologies and Global Practices; Nova Science Publishers, Inc.: New York, NY, USA, 2013; pp. 163-178.

76. Christoforou, E.; Fokaides, P.A. A review of olive mill solid wastes to energy utilization techniques. Waste Manag. 2016, 49, 346-363. [CrossRef] [PubMed]

77. Toledano, A.; Alegria, I.; Labidi, J. Biorefining of olive tree (Olea europea) pruning. Biomass Bioenergy 2013, 59, 503-511. [CrossRef]

78. Trebušak, T.; Levart, A.; Salobir, J.; Pirman, T. Effect of Ganoderma lucidum (Reishi mushroom) or Olea europaea (olive) leaves on oxidative stability of rabbit meat fortified with n-3 fatty acids. Meat Sci. 2014, 96, 1275-1280. [CrossRef]

79. Stoller, M.; Azizova, G.; Mammadova, A.; Vilardi, G.; Di Palma, L.; Chianese, A. Treatment of olive oil processing wastewater by ultrafiltration, nanofiltration, reverse osmosis and biofiltration. Chem. Eng. Trans. 2016, 47, 409-414. [CrossRef]

80. Sayadi, S.; Allouche, N.; Jaoua, M.; Aloui, F. Detrimental effects of high molecular-mass polyphenols on olive mill wastewater biotreatment. Proc. Biochem. 2000, 35, 725-735. [CrossRef]

81. Lozano-Garcia, B.; Parras-Alcantara, L.; Carillo, D.T.; de-Albornoz, M. Effects of olive mill wastes on surface soil properties, runoff and soil losses in traditional olive groves in southern Spain. Catena 2011, 85, 187-193. [CrossRef]

82. Magdich, S.; Jarboui, R.; Ben Rouina, B.; Boukhris, M.; Ammar, E. A yearly spraying of olive mill wastewater on agricultural soil over six successive years: Impact of different application rates on olive production, phenolic compounds, phytotoxicity and microbial counts. Sci. Total Environ. 2012, 430, 209-216. [CrossRef]

83. Buchmann, C.; Felten, A.; Peikert, B.; Munoz, K.; Bandow, N.; Dag, A.; Schaumann, G.E. Development of phytotoxicity and composition of a soil treated with olive mill wastewater (OMW): An incubation study. Plant. Soil. 2015, 386, 99-112. [CrossRef]

84. Steinmetz, Z.; Kurtz, M.P.; Dag, A.; Zipori, I.; Schaumann, G.E. The seasonal influence of olive mill wastewater applications on an orchard soil under semi-arid conditions. J. Plant. Nutr. Soil Sci. 2015, 178, 641-648. [CrossRef]

85. Chatzistathis, T.; Koutsos, T. Olive mill wastewater as a source of organic matter, water and nutrients for restoration of degraded soils and for crops managed with sustainable systems, a review. Agric. Water Manag. 2017, 190, 55-64. [CrossRef]

86. Koutsos, T.M.; Chatzistathis, T.; Balampekou, E.I. A new framework proposal, towards a common EU agricultural policy, with the best sustainable practices for the re-use of olive mill wastewater. Sci. Total Environ. 2018, 622, 942-953. [CrossRef]

87. Karpouzas, D.G.; Rousidou, C.; Papadopoulou, K.K.; Bekris, F.; Zervakis, G.; Singh, B.; Ehaliotis, C. Effect of continuous olive mill wastewater applications, in the presence and absence of $\mathrm{N}$ fertilization, on the structure of the soil fungal community. FEMS Microbiol. Ecol. 2009, 70, 56-69. [CrossRef]

88. Brunetti, G.; Senesi, N.; Plaza, C. Effects of amendment with treated and untreated olive oil mill wastewaters on soil properties, soil humic substances and wheat yield. Geoderma 2007, 138, 144-152. [CrossRef]

89. Zenjari, B.; Nejmeddine, A. Impact of spreading olive mill wastewater on soil characteristics: Laboratory experiments. Agronomie 2001, 21, 749-755. [CrossRef]

90. Lopez-Pineiro, A.; Murillo, S.; Barreto, C.; Munoz, A.; Rato, J.M.; Albarran, A.; Garcia, A. Changes in organic matter and residual effect of amendment with two-phase olive-mill waste on degraded agricultural soils. Sci. Total Environ. 2007, 378, 84-89. [CrossRef] 
91. Amaral, C.; Lucas, M.S.; Coutinho, J.; Crespi, A.L.; do Rosario Anjos, M.; Pais, C. Microbiological and physicochemical characterization of olive mill wastewaters from a continuous olive mill in Northeastern Portugal. Biores. Technol. 2008, 99, 7215-7223. [CrossRef]

92. Saadi, I.; Laor, Y.; Raviv, M.; Medina, S. Land spreading of olive mill wastewater: Effects on soil microbial activity and potential phytotoxicity. Chemosphere 2007, 66, 75-83. [CrossRef]

93. Ghaida, A.R. Effect of olive mill solid waste on soil physical properties. Int. J. Soil Sci. 2016, 11, 94-101.

94. Khdair, I.A.; Ghaida, A.R. Dataset on some soil properties improvement by the addition of olive pomace. Data Brief. 2019, 24, 103878. [CrossRef] [PubMed]

95. de Jong, E.; Jungmeier, G. Biorefinery concepts in comparison to petrochemical refineries. In Industrial Biorefineries \& White Biotechnology; Ashok, P., Rainer, H., Christian, L., Mohammad, T., Madhavan, N., Eds.; Elsevier: Waltham, MA, USA, 2015; pp. 3-33.

96. Zagklis, D.P.; Arvaniti, E.C.; Papadakis, V.P.; Paraskeva, C.A. Sustainability analysis and benchmarking of olive mill wastewater treatment methods. J. Chem. Technol. Biotechnol. 2013, 88, 742-750. [CrossRef]

97. El-Abbassi, A.; Kiai, H.; Hafidi, A. Phenolic profile and antioxidant activities of olive mill wastewater. Food Chem. 2012, 132, 406-412. [CrossRef]

98. Zbakh, H.; El Abbassi, A. Potential use of olive mill wastewater in the preparation of functional beverages: A review. J. Func. Foods 2012, 4, 53-65. [CrossRef]

99. Kishikawa, A.; Ashour, A.; Zhu, Q.C.; Yasuda, M.; Ishikawa, H.; Shimizu, K. Multiple biological effects of olive oil by-products such as leaves, stems, flowers, olive milled waste, fruit pulp, and seeds of the olive plant on skin. Phytother. Res. 2015, 29, 877-886. [CrossRef]

100. Dogruel, S.; Olmez-Hanci, T.; Kartal, Z.; Arslan-Alaton, I.; Orhon, D. Effect of Fenton's oxidation on the particle size distribution of organic carbon in olive mill wastewater. Water Res. 2009, 43, 3974-3983. [CrossRef]

101. Mantzavinos, D.; Psillakis, E. Enhancement of biodegradability of industrial wastewaters by chemical oxidation pre-treatment. J. Chem. Technol. Biotechnol. 2004, 79, 431-454. [CrossRef]

102. Comninellis, C.; Kapalka, A.; Malato, S.; Parsons, S.A.; Poulios, I.; Mantzavinos, D. Advanced oxidation processes for water treatment: Advances and trends for R\&D. J. Chem. Technol. Biotechnol. 2008, 83, 769-776.

103. Pera-Titus, M.; Garcia-Molina, V.; Banos, M.A.; Gimenez, J.; Esplugas, S. Degradation of chlorophenols by means of advanced oxidation processes: A general review. Appl. Catal. B Environ. 2004, 47, 219-256. [CrossRef]

104. Stefanakis, A.I.; Akratos, C.S.; Tsihrintzis, V.A. Vertical Flow Constructed Wetlands: Eco-Engineering Systems for Wastewater and Sludge Treatment, 1st ed.; Elsevier: Burlington, VT, USA, 2014.

105. Yalcuk, A.; Pakdil, N.B.; Turan, S.Y. Performance evaluation on the treatment of olive mill wastewater in vertical subsurface flow, constructed wetlands. Desalination 2010, 262, 209-214. [CrossRef]

106. Herouvim, E.; Akratos, C.S.; Tekerlekopoulou, A.G.; Vayenas, D.V. Treatment of olive mill wastewater in pilot-scale vertical flow constructed wetlands. Ecol. Eng. 2011, 37, 931-939. [CrossRef]

107. Michailides, M.; Tatoulis, T.; Sultana, M.-Y.; Tekerlekopoulou, A.G.; Konstantinou, I.; Akratos, C.S.; Vayenas, D.V. Start-up of a free water surface constructed wetland for treating olive mill wastewater. Chem. Ind. 2015, 69, 577-583. [CrossRef]

108. Sultana, M.; Chowdhury, A.K.M.M.B.; Michailides, M.K.; Akratos, C.S.; Tekerlekopoulou, A.G.; Vayenas, D.V. Integrated $\mathrm{Cr}(\mathrm{VI})$ removal using constructed wetlands and composting. J. Hazard. Mater. 2015, 281, 106-113. [CrossRef] [PubMed]

109. Aytar, P.; Gedikli, S.; Sam, M.; Farizog `u, B.; Cabuk, A. Sequential treatment of olive oil mill wastewater with adsorption and biological and photo-Fenton oxidation. Environ. Sci. Pollut. Res. 2013, 20, 3060-3067. [CrossRef]

110. Aktas, E.S.; Imre, S.; Ersoy, L. Characterization and lime treatment of olive mill wastewater. Water Res. 2001, 35, 2336-2340. [CrossRef]

111. Grafias, P.; Xekoukoulotakis, N.P.; Mantzavinos, D.; Diamadopoulos, E. Pilot treatment of olive pomace leachate by vertical-flow constructed wetland and electrochemical oxidation: An efficient hybrid process. Water Res. 2010, 44, 2773-2780. [CrossRef]

112. Cox, L.; Celis, R.; Hermosin, M.C.; Becker, A.; Cornejo, J. Porosity and herbicide leaching in soils amended with olive mill wastewater. Agric. Ecosyst. Environ. 1997, 65, 151-161. [CrossRef]

113. Gharaibeh, S.; Rababah, A.; Nishino, H. Low cost treatment and disposal of olive mill wastewater. Pollut. Solut. 2008, 9, 4-6. 
114. Al-Asheh, S.; Juma, R.; Banat, F.; Al-Zou'bi, A.; Al-Qutaish, N. Treatment of olive mills effluent using Electro-Osmosis Dewatering. Hydrol. Curr. Res. 2011, 2, 1-7.

115. Kapellakis, I.E.; Paranychianakis, N.V.; Tsagarakis, K.P.; Angelakis, A.N. Treatment of olive mill wastewater with constructed wetlands. Water 2012, 4, 260-271. [CrossRef]

116. Bani Salameh, W. Treatment of olive mill wastewater by ozonation and electrocoagulation processes. Global Adv. Res. J. Eng. Technol. Innov. 2015, 4, 69-78.

117. Benitez, J.; Beltran-Heredia, J.; Torregrosa, J.; Acero, J.L.; Cercas, V. Aerobic degradation of olive mill wastewaters. Appl. Microbiol. Biotechnol. 1997, 47, 185-188. [CrossRef] [PubMed]

118. Lafia, W.; Shannak, B.; Al-Shannaga, M.; Al-Anber, Z.; Hasan, M. Treatment of olive mill wastewater by combined advanced oxidation and Biodegradation. Sep. Purif. Technol. 2009, 70, 141-146. [CrossRef]

119. Cooperband, L. The Art and Science of Composting A Resource for Farmers and Compost Producers; University of Wisconsin-Madison, Center for Integrated Agricultural Systems: Madison, WI, USA, 2002; pp. 1-14.

120. Sanchez-Arias, V.; Fernandez, F.; Villasenor, J.; Rodriguez, L. Enhancing the co-composting of olive mill wastes and sewage sludge by the addition of an industrial waste. Bioresour. Technol. 2008, 99, 6346-6353. [CrossRef]

121. Vuppala, S.; Bavasso, I.B.; Stoller, M.; Palma, S.L.D.; Vilardi, G. Olive mill wastewater integrated purification through pre-treatments using coagulants and biological methods: Experimental, modelling and scale-up. J. Clean. Prod. 2019, 236, 117622. [CrossRef]

122. Vlyssides, A.G.; Loizides, M.; Karlis, P.K. Integrated strategic approach for reusing olive oil extraction by-products. J. Clean. Prod. 2004, 12, 603-611. [CrossRef]

123. Altieri, R.; Esposito, A.; Nair, T. Novel static composting method for bioremediation of olive mill waste. Int. Biodeterior. Biodegrad. 2011, 65, 786-789. [CrossRef]

124. Filidei, S.; Masciandaro, G.; Ceccanti, B. Anaerobic digestion of olive oil mill effluents: Evaluation of wastewater8 organic load and phytotoxicity reduction. Water Air Soil Poll. 2003, 145, 79-94. [CrossRef]

125. Ammary, B. Treatment of olive mill wastewater using an anaerobic sequencing batch reactor. Desalination 2005, 177, 157-165. [CrossRef]

126. Sobhi, B.; Isam, S.; Ahmad, Y.; Jacob, H. Reducing the environmental impact of olive mill wastewater in Jordan, Palestine and Israel. Water Resour. Middle East. Eds Hillel Shuval Hassan Dweik 2007, 2, 409-415.

127. Khatib, A.; Aqra, F.; Yaghi, S.Y.; Hayeek, B.; Musa, M.; Basheer, S.; Sabbah, I. Reducing the environmental impact of olive mill wastewater. Am. J. Environ. Sci. 2009, 5, 1-6.

128. Al-Qodah, Z.; Al-Bsoul, A.; Assirey, E.; Al-Shannag, M. Combined ultrasonic irradiation and aerobic biodegradation treatment for olive mills wastewaters. Environ. Eng. Manag. J. 2014, 13, 2109-2118.

129. Masghouni, M.; Hassairi, M. Energy applications of olive-oil industry by-products: I. The exhaust foot cake. Biomass Bioenerg 2000, 18, 257-262. [CrossRef]

130. Saviozzi, A.; Levi-Minzi, R.; Cardelli, R.; Biasci, A.; Riffaldi, R. Suitability of moist olive pomace as soil amendment. Water Air Soil Pollut. 2001, 128, 13-22. [CrossRef]

131. Thompson, R.B.; Nogales, R. Nitrogen and carbon mineralization in soil of vermi-composted and unprocessed dry olive cake ("orujo seco") produced from two-stage centrifugation for olive oil extraction. J. Environ. Health Sci. B 1999, 34, 917-928. [CrossRef]

132. Tekin, A.R.; Dalgic, A.C. Biogas production from olive pomace. Resour. Conserv. Recycl. 2000, 30, 301-313. [CrossRef]

133. Alcaide, E.M.; Ruiz, D.Y.; Moumen, A.; García, A.M. Ruminal degradability and in vitro intestinal digestibility of sunflower meal and in vitro digestibility of olive by-products supplemented with urea or sunflower meal: Comparison between goats and sheep. Anim. Feed Sci. Technol. 2003, 110, 3-15. [CrossRef]

134. Cayuela, M.L.; Bernal, M.P.; Roig, A. Composting olive mill wastes and sheep manure for orchard use. Compos. Sci. Util. 2004, 12, 130-136. [CrossRef]

135. Cardoso, S.M.; Coimbra, M.A.; Lopes da Silva, J.A. Calcium mediated gelation of an olive pomace pectic extract. Carbohyd. Polym. 2003, 52, 125-133. [CrossRef]

136. Karkoula, E.; Skantzari, A.; Melliou, E.; Magiatis, P. Direct measurement of oleocanthal and oleacein levels in olive oil by quantitative $1 \mathrm{H}$ NMR. Establishment of a new index for the characterization of extra virgin olive oils. J. Agric. Food Chem. 2012, 60, 11696-11703. [CrossRef] 
137. Boucid, O.; Navarro, D.; Roche, M.; Asther, M.; Haon, M.; Delattre, M.; Lorquin, J.; Labat, M.; Asther, M.; Lesage-Meessen, L. Fungal enzymes as a powerful tool to release simple phenolic compounds from olive oil by-product. Process. Biochem. 2005, 40, 1855-1862. [CrossRef]

138. Pagnanelli, F.; Esposito, A.; Veglio, F. Multi-metallic modeling for biosorption of binary systems. Water Res. 2002, 36, 4095-4105. [CrossRef]

139. Cox, L.; Hermosı́n, M.C.; Cornejo, J. Influence of organic amendments on sorption and dissipation of imidacloprid in soil. Int. J. Environ. Anal. Chem. 2004, 84, 95-102. [CrossRef]

140. Albarrán, A.; Celis, R.; Hermosın, M.C.; López-Piñeiro, A.; Cornejo, J. Behavior of simazine in soil amended with the final residue of the olive oil extraction process. Chemosphere 2004, 54, 717-724. [CrossRef]

141. Siracusa, G.; La Rosa, A.D.; Siracusa, V.; Trovato, M. Ecocompatible use of olive husk as filler in thermoplastic composites. J. Polym. Environ. 2001, 9, 157-161. [CrossRef]

(C) 2020 by the authors. Licensee MDPI, Basel, Switzerland. This article is an open access article distributed under the terms and conditions of the Creative Commons Attribution (CC BY) license (http://creativecommons.org/licenses/by/4.0/). 